УДК 656.223.2

Канд. техн. наук О.М. Костєнніков

\title{
ПЕРСПЕКТИВИ РОЗВИТКУ КОНТЕЙНЕРНИХ ПОЇЗДІВ У НАПРЯМКУ МІЖНАРОДНИХ ТРАНСПОРТНИХ КОРИДОРІВ ТА ТЕРИТОРІЄЮ УКРАЇНИ
}

\author{
Представив д-р техн. наук, професор О.М. Огар
}

\begin{abstract}
Вступ та аналіз попередніх досліджень. Основною тенденцією в розвитку вітчизняного та світового транспорту $\epsilon$ швидке зростання контейнерних перевезень, які в максимальній мірі відповідають вимогам ринкової економіки. Обсяги перевезених вантажів у контейнерах залізницями України за I квартал 2013 року зросли на $8 \%$ у порівнянні із відповідним періодом минулого року. Тепер територією України організовано та курсує 14 контейнерних поїздів. Перевезення контейнерів у складі контейнерних поїздів становлять $40 \%$ від загального обсягу перевезених контейнерів територією України. За I квартал 2013 року територією України у складі контейнерних
\end{abstract}

поїздів перевезено 12695 контейнерів. Протягом 2012 року територією України у складі контейнерних поїздів перевезено 60886 контейнерів, що на 35\% більше від обсягів перевезених контейнерів у складі контейнерних поїздів за 2011 рік (у 2011 році перевезено 45247 контейнерів).

У 2013 році Укрзалізницею у співпраці 3 Словацькою державною залізничною вантажною компанією ЗССК Карго та ВАТ «РЖД» організовано контейнерний поїзд за маршрутом Словаччина - Україна (Ужгород - Зернове) Росія (Суземка - Нижній НовгородАвтозавод) та у зворотному напрямку. Пілотний рейс нового контейнерного поїзда Чехія - Словаччина - Україна - Росія 
відбувся 23 червня 2013 року. Передбачуваний обсяг перевезень становить 600 контейнерів на місяць (13-14 поїздів) [1].

Контейнерні поїзди дозволяють: знижувати терміни доставки контейнерних вантажів, що перевозяться залізничним транспортом; збільшувати роботу контейнерів i вагонів за рахунок скорочення їхнього обороту; зменшувати обсяг сортування на станціях. Перевезення контейнерів у наскрізних поїздах до місць призначення виключають переробку на сортувальних станціях, а також підвищують схоронність вантажів і контейнерів.

$\begin{array}{cccc}\text { Виклад } & \text { основного } & \text { матеріалу. } \\ \text { Фактор часу } & \text { на } & \text { транспорті }\end{array}$
характеризується тим, як розподіляється транспортне виробництво, в який термін виконується транспортна послуга. Скорочення тривалості транспортного процесу, транспортного циклу дає суспільству в цілому i кожній людині окремо величезні вигоди. Візьмемо, наприклад, економіку. Чим швидше продукт доходить до споживача, тим інтенсивніше збільшується кругообіг виробництва i відтворення. Якщо не виконується принцип - доставка «точно в строк», то необхідно робити запаси сировини. А зміна запасу сировини, палива, напівфабрикатів знижує ефективність виробництва. Швидкість доставки вантажів, ритмічність, надійність мають велике економічне значення. Транспортування не створює нових продуктів, але здорожує їх вартість. Низькі швидкості доставки, затримки, перебої та ін. впливають на вартість товару. Природно, що чим менше та вартість, яку додає транспорт до товару, тим ефективніше вплив транспорту на суспільне виробництво в цілому. $\mathrm{He}$ випадково в ході історичного розвитку людина прагнула з'єднати віддалені одна від одної точки планети, скоротити час на переміщення між ними [2].
Збільшення швидкості доставки на транспорті можливо шляхом скорочення часу переміщення і часу, необхідного для виконання транспортної діяльності. Одна 3 важливих форм оптимізації технології роботи 3 контейнерами - організація контейнерних поїздів. Це дозволяє відправляти великі партії контейнерів через регулярні інтервали часу і дає тим більший ефект, чим більше відстань, на яку виконується перевезення. Тимчасові властивості цієї послуги пов'язані 3 точністю i регулярністю руху. Таким чином, першою умовою організації контейнерного поїзда $€$ скорочення величини терміну доставки. Його можна записати у вигляді [3]

$$
T_{\text {ван }} \geq T_{\kappa n}
$$

де $T_{\text {ван }}$ - величина терміну доставки при перевезенні контейнерів у вантажних поїздах за планом формування, доб;

$T_{\kappa n}$ - величина терміну доставки при перевезенні контейнерів в контейнерному поїзді, доб.

В даний час на залізницях України терміни доставки вантажів обчислюються виходячи з відстані, за яку нараховується провізна плата, з урахуванням залізничних напрямів, за якими здійснюються перевезення вантажів, а також часу, необхідного для виконання додаткових операцій. Величину терміну доставки можна визначити за такою формулою:

$$
T \geq \frac{L}{V_{\text {конт }}}+t_{\text {дод }},
$$

де $L$ - дальність перевезення вантажу в контейнерах, км;

$V_{\text {конт }}$ - швидкість перевезення вантажів у контейнерах, км / доб;

$t_{\text {до }}$ - час на додаткові операції в процесі перевезення, доб. 
Організація контейнерних поїздів дозволяє значно скоротити величину терміну доставки вантажів у контейнерах. Проте в даному випадку зростуть затримки вантажу на складах вантажовідправників, так як відправлення контейнерних поїздів здійснюється через певні проміжки часу. Величину інтервалу між відправленням контейнерних поїздів можна визначити за формулою

$$
I_{\kappa n}=\frac{m_{\kappa n}}{u_{\text {ооб }}},
$$

де $m_{k n}$ - величина складу контейнерного поїзда, ваг;

$u_{\text {доб }}{ }^{-}$розрахунковий розмір добового вагонопотоку, ваг.

Тривалість затримки вантажів на складах вантажовідправників визначається величиною інтервалу між відправленням контейнерних поїздів. Її максимальну величину можна визначити за формулою

$$
T_{3}^{\max }=l_{\kappa n} k_{0}-\left(t_{3 а в}^{\kappa n}-1\right)-T_{\text {зав }},
$$

де $k_{0}$ - коефіцієнт, що характеризує зменшення витрат на зберігання вантажів на складах відправників у зв'язку 3 можливістю відправлення їх при календарному плануванні в інші призначення;

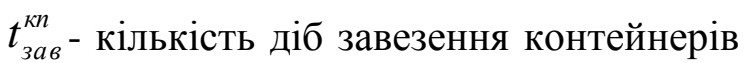
на один поїзд, доб;

$T_{\text {зав }}$ - тривалість завезення контейнерів на станцію протягом доби, доб.

Отже, першу умову організації контейнерних поїздів можна записати у вигляді

$$
T_{3}^{\max } \leq T_{2 p}-T_{\kappa n},
$$

Перевірка за цією умовою дозволяє виділити призначення, на які доцільно розглянути можливість організації контейнерних поїздів. Також необхідно враховувати витрати, пов'язані з вартістю вантажів, що знаходяться в процесі доставки від складів відправників до складів одержувачів.

Таким чином, другою умовою організації контейнерних поїздів $\epsilon$

$$
P_{\kappa n} \leq P_{\text {ван }}
$$

де $P_{\kappa n}$ - сумарні приведені витрати 3 доставки контейнерів $\mathrm{y}$ контейнерному поїзді, грн;

$P_{\text {ван }}$ - сумарні приведені витрати 3 доставки контейнерів у вантажних поїздах за планом формування, грн.

У разі, коли питання про організацію контейнерних поїздів має вирішуватися окремо, з урахуванням додаткових умов, за отриманим призначенням плану формування необхідно перевірити можливість організації контейнерних поїздів.

Висновок та перспективи подальших досліджень. Можливість організації контейнерних поїздів для заданого призначення доцільно визначати 3 двох умов. Першою $є$ умова скорочення величини терміну доставки. Використання такої умови дозволяє відібрати призначення для подальшої перевірки без виконання трудомістких обчислень. Відібрані призначення перевіряються за другою умовою - ефективність організації контейнерних поїздів.

Слід відмітити, що при перевезенні контейнерними поїздами діють спеціальні (міждержавні) тарифні умови та спрощені процедури митного та прикордонного огляду контейнерів. Разом з тим, необхідно підвищувати рентабельність та конкурентоспроможність контейнерних поїздів за рахунок оптимальних співвідношень між вартістю перевезень, часом доставки вантажу i поверненням порожніх контейнерів. 


\section{Список літератури}

1. Новини міністерств та відомств [Електронний ресурс]: Обсяги перевезення вантажів у контейнерах територією України за I квартал збільшилися на 8\%. Режим доступу: http://www.kmu.gov.ua/control/uk/publish/article?art_id=246306490\&cat_id=244277212.

2. Капітонов, О.С. Організація контейнерних перевезень на основі принципів логістики [Текст]: дис... канд. техн. наук / О.С. Капітонов. - С.Пб., 2001. - 275 с.

3. Ковров, П.А. Эффективность и сферы применения контейнерних поездов [Текст] / П.А. Ковров. - Л.: ЛИИЖТ, 1979. - 36 с.

Ключові слова: контейнер, контейнерний поїзд, строк доставки, провізна плата.

\section{Анотаціï}

Проведено аналіз перевезення контейнерів контейнерними поїздами в напрямку міжнародних транспортних коридорів, а також територією України. Охарактеризовано переваги та недоліки контейнерних поїздів. Наведено умови доцільності формування контейнерних поїздів.

Проведен анализ перевозки контейнеров контейнерными поездами в направлении международных транспортных коридоров, а также по территории Украины. Охарактеризованы преимущества и недостатки контейнерных поездов. Приведены условия целесообразности формирования контейнерных поездов.

Analysis of containers transportation be means of container trains in direction to international transport corridor as well as in Ukraine is conducted. Advantages and disadvantages of container trains are characterized. Specifications for appropriate formation of container trains. 